\title{
Serial SARS-CoV-2 Seropravelence Studies in Delhi July-August 2020: Indications of Pre-existing Cross-reactive Antibodies and Implications for Disease Progression
}

Smarajit Dey ( $\sim$ drsdeynew@gmail.com )

Independent Consultant https://orcid.org/0000-0001-9281-2169

Research Article

Keywords: SARS-CoV-2 Antibodies, Seroprevalence, India Covd19, Cross-reactive antibodies, Serostudies, Delhi serosurveys, COVID KAVACH ELISA, Delhi Covid 19 Progression

Posted Date: September 21st, 2020

DOl: https://doi.org/10.21203/rs.3.rs-80259/v1

License: (c) (1) This work is licensed under a Creative Commons Attribution 4.0 International License. Read Full License 


\section{Abstract}

Two seropravelence studies were undertaken in Delhi, the city-state capital of India, in July-August 2020, exactly one month apart, to test for SARS-CoV-2 antibodies. Virus-tested (mostly RT-PCR) caseloads corresponding to these surveys, as of 13 days earlier to ensure antibody generation, were compared. The survey conducted June 26-July 10 (sample size 21387) showed 23.48\% seropravelence, (extrapolated to $4.48 \mathrm{mn}$ of Delhi population of $19.1 \mathrm{mn}$ ), which was 79-times higher than corresponding virus-tested positives totaling 56746. Survey conducted August 1-7 (15311 samples) showed $29.1 \%$ antibodypositive (5.56 mn population), and was 44x of virus-tested positive total of 125096 . Pointing out that all serological surveys world-over have shown antibody-positives to be higher than virus-test positives by multiples $7 x$ to $80 x$, this study seeks to examine why the multiple should decline so drastically in one month, from 79x to 44x.

Statistical adjustments were performed for Sampling Error and Sensitivity/Specificity of the diagnostic kits. Indigenously developed COVID KAVACH ELISA tests for IgG antibodies to the SARS-CoV-2 virus were used for the surveys. Significantly, statistical adjustments were also done to account for the Testing Volumes and (Spot) Positivity rates at the two different times. [Spot Positivity is defined in the study and is the closest estimate of current or fresh positivity.] After all statistical revisions, the antibody-positive to virus-test positive multiples stood at $53 x$ and $37 x$ for the two surveys. Calculating across the two sets of data, and other sensitivity analysis, the study indicates that there is a significant proportion of preexisting cross-reactive antibodies (possibly to the HCOV viruses), that are seropositive in SARS-CoV-2 antibody tests, to the extent of 16\%-19\% of the population. The study also infers that there is an Amplification Factor of 15 in the Delhi serostudies: ie, each virus-test positive represents 14 more who are possibly asymptomatic and untested.

The study forecasts a seropravelence $31 \%-34 \%$ for the $3^{\text {rd }}$ serial serosurvey scheduled in September, whose results expected $22^{\text {nd }}$ September. Limitations of the study are discussed, notably the absence of any research paper on the survey techniques, antibody testing controversies, and the statistical adjustment for Testing Volumes. The study discusses how Chain-ofTransmission protocols and Decreasing Susceptible Population work in unison to slow down a pandemic, and analyses the disease progression graph of Delhi in that context. The implications of 16\%-19\% pre-existing antibodies on disease progression in Delhi are discussed.

\section{Main Text}

The National Centre for Disease Control (NCDC) India conducted a serological survey for IgG antibodies to SARS-CoV-2 virus in the state of Delhi, India - a city-state and the capital of the country - between June 26 and July 10, 2020(1), median date July 3. A second serological survey was conducted by the Government of Delhi on the same population, from August 1-7 2020(2), median date August 3. Table 1 below provides details of these surveys and results, considering Delhi's population as 19.1 million $^{(3)}$. The median time to develop IgG antibodies is 13 days from symptom onset ${ }^{(4)}$, so these serosurveys correspond to those infected by the virus latest by June $20^{\text {th }}$ and July $21^{\text {st }}$, respectively.

\begin{tabular}{|c|c|c|c|c|c|c|c|c|}
\hline $\begin{array}{l}\text { Surv } \\
\text { No. }\end{array}$ & $\begin{array}{l}\text { Survey } \\
\text { Dates }\end{array}$ & $\begin{array}{l}\text { Median } \\
\text { Date }\end{array}$ & $\begin{array}{l}\text { Sample } \\
\text { Size }\end{array}$ & $\begin{array}{l}\text { Positivity } \\
\text { Detected } \\
\text { (antibody } \\
\text { +ve) }\end{array}$ & $\begin{array}{l}\text { Implies, } \\
\text { infected... }\end{array}$ & $\begin{array}{l}\text { Corresponding } \\
\text { "Infected" Dt }\end{array}$ & $\begin{array}{l}\text { Tot virus-test } \\
\text { +ve by date }\end{array}$ & $\begin{array}{l}\text { Multiple of Antibody } \\
\text { +ve to Virus +ve }\end{array}$ \\
\hline 1 & $\begin{array}{l}\text { June } \\
26-J u l y \\
10\end{array}$ & July 3 & 21,387 & $23.48 \%$ & 4.48 mill & By June 20 & 56,746 & 79-times \\
\hline 2 & $\begin{array}{l}\text { Aug } 1 \text { - } \\
7\end{array}$ & Aug 3 & 15,311 & $29.1 \%$ & 5.56 mill & By July 21 & 125,096 & 44-times \\
\hline
\end{tabular}


Table 1 shows that while there were 56746 infected cases (2971 per $\mathrm{mn}$ ) - all tested for virus positivity by RT-PCR, negligible RAT testing, there were $4.48 \mathrm{mn}$ (234,800 per $\mathrm{mn}$ ) seropositive cases - positive for the presence of SAR-CoV-2 antibodies. By conventional wisdom, $4.48 \mathrm{mn}$ residents had contracted Covid-19 and had developed antibodies thereafter. Those antibodypositive cases were 79 times higher than virus-tested cases. These were "invisible" cases - not only were they adequately asymptomatic to not require medical attention, but they had not also been tested as primary contacts of infected cases. Similarly, for the second survey, there were 6550 virus-positive cases per million, while there were 291,000 per million seropositive, a multiple for $44 x$.

\section{The Research Question}

Although it is surprising that seropositive cases should be much higher than those recorded infected by virus testing, this result is consistent with other studies across the world (see following section). However, it is intriguing that the gap between serosurvey positives and virus-test positives should fall so much - 79 times down to 44 times - in the course of 1 month.

The objective of this study is not to establish that antibody-positive cases are higher in Delhi than recorded-infected cases or to examine why the multiples are as high as $79 x$, though the study will provide some answers to these questions. The objective of this study is to scrutinize why multiple antibody-tested positive cases fell from $79 x$ in June-July to $44 x$ exactly one month later.

This phenomenon is counterintuitive. If there are "invisible" asymptomatic untested cases who have recovered and developed antibodies, as high as 79 times the recorded numbers at any point of time, this multiple should remain similar at second and subsequent surveys. If the natural phenomenon is that invisible cases infect others because they are without quarantine or isolation, they should continue doing so at all times.

There is one possibility that testing volumes were low until June $20^{\text {th }}$, and consequently, a number of symptomatic cases were untested in that period but soon fully recovered with active antibodies that showed up in the first survey. A look at the data leads to the intuitive conclusion that virus-tested positives would not have gone up to comparable levels even if testing volumes were higher before the first serosurvey. We establish this intuitive conclusion by the statistical revisions we perform, using testing volumes and spot positivity, to "equate" the two surveys on this parameter. [We define the term Spot Positivity to mean Current or Fresh Positivity Rates of Virus-tests; Spot Positivity on Day D is defined as the (Total of Fresh Cases on Days D, D+1, D+2) divided by (Total of Fresh Tests conducted on Day D-1, D and D+1)]

\section{Background: Antibody-tested Positives are Always Higher than Virus-tested Positives}

There is no debate that the total number of those who will go on later to develop antibodies will always be higher than the recorded positive cases. Many infected cases, mostly asymptomatic, are untested. Testing capacity and protocols are not designed to hunt for asymptomatic cases. Practical testing logistics limits testing to symptomatic cases and their primary contacts and excludes asymptomatic cases and secondary contacts. For these and other reasons, there will always be a number of "invisible" Covid-19 cases in the community.

This has been established time and again. All serological surveys conducted so far have indicated an antibody-positive number in excess of virus-tested positive cases, with the range varying between $6 x$ and $80 x$. Among a few such, a study in Gangelt Germany in March 2020(5) revealed a 7-fold higher seroprevalence than confirmed infected cases. A widely cited study in The Lancet $^{(6)}$ conducted in Geneva during April-May reached the definitive conclusion that antibody-positive cases were $11.6 \mathrm{x}$ higher than virus-tested positive cases. A study conducted at 10 diverse sites in the USA between Mar-May $2020^{(7)}$ showed an average gap of 38x between seroprevalent cases versus recorded-infected cases (counted 7 days prior to antibody testing) the multiple varied widely across the 10 sites. A study in Spain involving 61075 samples conducted in April-May ${ }^{(8)}$ showed seroprevalence between $3.7 \%$ and $6.2 \%$ and an antibody-positive figure that is at least $19 x$ the virus-positive cases (after extrapolating the math in the paper). Several other studies ${ }^{(8)}$ report seroprevalence data without comparing with corresponding recorded-infected cases - if computed, these would also reveal significantly higher multiples of antibody-positive cases. It can be inferred that an unstated informal consensus is that seroprevalent cases 10x-15x higher than recorded infected cases are not unusual. 
Interestingly, two of the studies cited above have reported a drop between two serial serostudies - in Geneva and some sites of USA - but these have been considered non-typical aberrations in only one subsequent round of testing. These have been seen in light of the possibility that antibodies may decrease over time. This is an unresolved question, with other research upholding both sides of the argument, and we will not factor-in the possibility of antibody decrease in our study.

\section{Background: A Basic View of Viral Dynamics and Antibody Generation}

With a large number of asymptomatic cases, the classical picture of exposed à incubation à onset à mild/moderate/severe disease à resolution is now inadequate. A study of viral dynamics is unwarranted in this study, but the relevant context is presented in Fig 1 below. This is a simplified schematic that shows the time relationships between the disease (detection and later), infectivity and antibody generation. The schematic is simplified by the use of median values when each element is actually a probability distribution. Exceptions arising from some recent research (e.g., no antibody generation) are avoided. Viral shedding is detected by RT-PCR testing; however, this oversensitive test will also detect viruses that are not alive (cannot be cultured) and hence do not contribute to active disease in the patient. The patient remains infective as long as the virus is live, and there is generally a phase-out of infectivity simultaneously with a phase-in of seroconversion (antibody generation). Fig 1 below is self-explanatory.

\section{Statistical Adjustments Prior to Analysis}

Raw data regarding total infected cases and seropravelence for the two serosurveys are given below:

Situation, originally; (Per mil population, corresponding seroprevalence data approx. 15 days later)

Case 1: As of $20^{\text {th }}$ June, the total Covid-infected (virus test) was 2971, and the antibody-test positive was 234,800 (79x).

Case 2: As of $21^{\text {st }}$ July, the total Covid-infected (virus-test) was 6550, and the antibody-test positive was 291,000 (44x).

Sampling Error. Extrapolating readings from a sample for the population may result in errors. The sample sizes for the two surveys were 25387 and 15311 , respectively, with results $23.48 \%$ and $29.1 \%$ positive. The Adjusted Wald approach ${ }^{(12)}$ adjusts for the population extrapolation by computing a confidence interval with a $95 \%$ confidence level of this assertion. The confidence intervals were [22.96\% - 24.01\%] for the first survey and [28.51\% - 29.95\%] for the second survey. We take the lower bound in both cases to avoid inflating the sampling bias. The resultant revision is below.

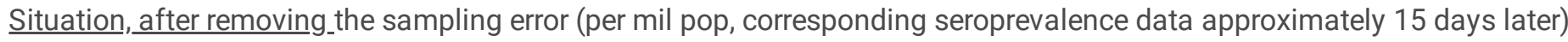

Case 1: As of $20^{\text {th }}$ June, the total Covid-infected (virus test) was 2971, and antibody-test positive was 229,600 (77x).

Case 2: As of $21^{\text {st }}$ July, the total Covid-infected (virus-test) was 6550, and antibody-test positive was 285,100 (44x).

Error of Sensitivity/Specificity of Diagnostic Kits. Both surveys used the KOVID KAVACH ELISA test, indigenously developed by the National Institute of Virology, Pune. This test quantifies IgG antibodies against the spike glycoprotein of the SARS-CoV-2 virus. The developers report ${ }^{(13)}$ a sensitivity of $\mathbf{9 2 . 3 7 \%}$ and a specificity of $\mathbf{9 7 . 9 \%}$. [These figures were unnecessarily mystified by a hasty Press Release by Indian Council of Medical Research (ICMR), reporting far-higher Specificity/Sensitivity scores ${ }^{(14)}$, subsequently amended.] After adjusting for false positives and false negatives by standard formula (15)

\section{Actual Prevalence Rate $=($ Seropravelence $\times$ Sensitivity $)+(1-$ Specificity $) \times(1-$ Seropravelence $)$}

The actual prevalence rate computes as 22.83\% for Survey 1 and $27.84 \%$ for Survey 2.

After removing Sampling and Diagnostic Kit Errors: $\quad$ (Per mn pop, corresponding seroprevalence data 15 days later)

Case 1: As of $20^{\text {th }}$ June, the total Covid-infected (virus test) was 2971, and antibody-test positive was 228,300 (77x). 
Case 2: As of $21^{\text {st }}$ July, the total Covid-infected (virus-test) was 6550, and the antibody-test positive was 278,400 (43x).

Adjusting for Testing Volumes. On $20^{\text {th }}$ June, when there were 2971 cumulative infected cases per million, a total of 351,909 tests were conducted. Over subsequent days, fresh tests added to the cumulative total until $13^{\text {th }}$ July (by when 789853 tests), when the Government of Delhi notified that "reconciliation with ICMR figures" had led to a reduction of 97008 tests cumulatively ${ }^{(16)}$. We have prorated this reduction across all previous days from $12^{\text {th }}$ July. Data details are provided in Table 2 below. For some key dates, including $20^{\text {th }}$ June and $21^{\text {st }}$ July, the two equivalent dates for virus-tested positive cases correspond to the two serosurveys. We also provide in the table the Cumulative Covid Positivity Rate (Total Infections divided by Total Tests), as well as the Spot Positivity Rate on these dates. Spot Positivity Rate, as defined earlier, provides the best estimate of Fresh (Current) Positivity on a given date.

\begin{tabular}{|c|c|c|c|c|c|c|c|c|c|}
\hline \multirow{2}{*}{$\begin{array}{l}\text { Cumulative } \\
\text { by Date OR } \\
\text { As on Date }\end{array}$} & \multicolumn{6}{|c|}{ Cumulative Covid Positivity Rate } & \multicolumn{3}{|c|}{ Spot Positivity Rate } \\
\hline & $\begin{array}{l}\text { Total } \\
\text { Infections } \\
\text { till date }\end{array}$ & $\begin{array}{l}\text { Total } \\
\text { Tests till } \\
\text { date }\end{array}$ & $\begin{array}{l}\text { Adjusted } \\
\text { Tests till } \\
\text { Date }\end{array}$ & $\begin{array}{l}\text { Total } \\
\text { Infections } \\
\text { per mn }\end{array}$ & $\begin{array}{l}\text { Total } \\
\text { Tests } \\
\text { per } \\
\text { mn }\end{array}$ & $\begin{array}{l}\text { Cumulative } \\
\text { Covid } \\
\text { Positivity } \\
\text { Rate }\end{array}$ & $\begin{array}{l}\text { Fresh } \\
\text { Infections } \\
\text { days } D \\
D+1, D+2\end{array}$ & $\begin{array}{l}\text { Fresh } \\
\text { Tests } \\
\text { days } \\
D-1, D \text {, } \\
D+1\end{array}$ & $\begin{array}{l}\text { Spot } \\
\text { Positivity } \\
\text { on Day D }\end{array}$ \\
\hline 20-Jun & 56746 & 351909 & 308688 & 2971 & 16162 & $18.38 \%$ & 9539 & 42729 & $22.32 \%$ \\
\hline 21-Jul & 125096 & 851311 & 851311 & 6550 & 44571 & $14.70 \%$ & 3617 & 52432 & $6.90 \%$ \\
\hline 20-Aug & 157354 & 1375193 & 1375193 & 8238 & 72000 & $11.44 \%$ & 3877 & 55554 & $6.98 \%$ \\
\hline 6-Sep & 191449 & 1780512 & 1780512 & 10024 & 93221 & $10.75 \%$ & 8942 & 97895 & $9.13 \%$ \\
\hline
\end{tabular}

We wish to adjust the Infected Cases to account for Testing Volumes and Positivity - i.e., we want to forecast how many additional Infected Cases would grow with increased volume of tests. We deal with two different forces at play. In a short time frame of a day or two, additional tests until a point would detect Covid-positive patients at the same rate as the Spot Positivity Rate; tests beyond that point would begin to detect more negative cases, reducing Spot Positivity. Over a longer time frame, fresh infections would emerge at a rate increasing or decreasing depending upon the disease trajectory in the community. In both the short run and the long run, it is difficult to forecast the outcome in terms of additional infected cases detected.

In perhaps the only study of its kind, Favero ${ }^{(17)}$ identifies a statistical basis to adjust case counts with respect to testing volume by adjusting for current positivity rate. By Favero's rule, the Total Outbreak number, or Adjusted Infected Cases, depends on the Spot Positivity at the time and is expressed as:

\section{Adjusted Infected Cases $=$ Actual Infected Cases $\times[1+$ (Positivity Rate $\times 100 \times$ Constant)], Constant=.01 $\rightarrow .02$}

For example, assuming the constant to be 0.02 , for 2971 cases per million at a Spot Covid Positivity Ratio of $22.32 \%$, the Adjusted Confirmed Cases works out to 4297 per million on June 20. Obviously, the Adjusted Infected Cases or Total Outbreak Number will match the testing strategy adopted. If the strategy is to test only 18-year-olds, the total outbreak number will only be with respect to 18-year-olds. Alternatively, if the strategy is to test high-incidence areas, the total outbreak number will reflect only those high-incidence areas. The Total Outbreak Number or Adjusted Infected Cases is not a miracle formula for the total confirmed cases in the world!

We assume a constant $=0.02$ for our exercise. Given positivity $22.32 \%$ on $20^{\text {th }}$ June and $6.9 \%$ on $21^{\text {st }}$ July, actual infected cases will rise to 4297 and 7454 per million, instead of the initial scores of 2971 and 6550 per million, respectively.

Removing Sampling and Diagnostic Kit Errors \& Adjusting for Testing Volumes:

(Per million population, corresponding seroprevalence data approx. 15 days later) 
Case 1: As of June 20, the number of adjusted infected cases (virus test) was 4297, and the number of antibody-test-positive cases was $228,300(53 x)$.

Case 2: As of July 21, the number of adjusted infected cases (virus test) was 7454, and the number of antibody test-positive cases was $278,400(37 x)$.

\section{Analysis of Differences in Seropravelence Multiples Over Two Studies}

On $20^{\text {th }}$ June, there were 53 times more antibody positive cases compared to recorded virus positives, and by $21^{\text {st }}$ July, this multiple had gone down to 37x. Between the two dates, virus-tested cases increased by 3157 per million, but antibody-positive cases increased by only 16 times (50100 per mn), not by 53 times as would be expected. This seems to mimic the linear equation $y=m x+c$, where the antibody positives $(y)$ equals a linear increase $m x$ ( $x$ are the virus-positives, and $m$ is 16 above), plus a constant $c$.

This phenomenon is explained if there is a proportion of the population that has preexisting SARS-CoV-2 antibodies without having gone through the disease. If say, 150,000 per million have pre-existing_antibodies (15\%), then those developing antibodies after undergoing disease will roughly be a constant multiple of virus-positive cases. Our research question - why is there a drop in the multiples between two studies - would be answered by the existence of a population with pre-existing antibodies, and the multiple would then not change between studies.

We develop this model analytically and then solve for the values:

1. Let $\mathrm{X}$ be the number per million within the population with pre-existing SARS-CoV-2 antibodies, or equivalent, such that they test positive to Covid 19 antibody tests without having undergone the disease. Equivalently, $X$ divided by 10,000 is a percentage that is the non-susceptible population, and (100 - this \%) is the percentage of the population susceptible.

2. Seropravelence (expressed as a number found antibody-positive per million), less $X$, is the actual number of seroprevalent individuals who developed antibodies after contracting the disease. This follows from (1) above, where X (per million) seropositive were pre-existing Therefore, [Seroprevalent number $-\mathrm{X}$ ] are those (per $\mathrm{mn}$ ) who acquired antibodies and can be numerically compared with virus-tested positive cases.

3. Let $\mathrm{F}$ be the Amplification Factor of virus-tested positive cases to account for the known phenomenon that the actual number of silent, asymptomatic, invisible Covid-19 cases and/or untested cases is invariably higher than recorded virustested positives. In other words, virus-positive (as a number of people tested positive per million) multiplied by $\mathrm{F}$ is the actual number of cases with Covid 19.

4. [Virus-Positive x F] must equal [Seroprevalence -X]. In other words, those virus-tested-positive multiplied by the Amplification Factor (F) of asymptomatic invisible cases must equal the number of acquired-seroprevalent cases, e., seroprevalent minus those pre-existing seroprevalent.

We fit the data from the two surveys after all statistical adjustments:

[Virus-tested-positive] x F = [Seroprevalence $-\mathrm{X}]$

4297 x F = $228300-X$... from Survey 1 , where figures are per million population, and $F$ is unit-less

and, 7454 x F = $278400-X$... from Survey 2

Solving the set of simultaneous equations leads to $\underline{X=160150}$, and $\underline{F=15.86}$

A total of 160150 per million, or $16.02 \%$, are pre-existing with SARS-CoV-2 antibodies without having undergone the disease. Every virus-tested positive case represents 15.9 Covid-infected people, implying that 14.9 people were uncounted as possibly asymptomatic cases. 
The discussion so far presumes the presence of pre-existing SARS-CoV-2 antibodies. However, these could equally be other antibodies cross-reactive with the SARS-CoV-2 antigen. This has been frequently reported in recent literature. Both Van der Heide $^{(18)}$ and Ma et al ${ }^{(19)}$ in research published in June 2020 and August 2020 report the cross-reactivity of endemic human coronavirus (HCoV) antibodies against SARS-CoV-2, in one case as high as $10 \%$ among individuals not exposed to SARS-CoV-

2. Pre-existing cross-reactive antibodies mean that antibodies generated after some other infection are effective against SARSCoV-2. This is more likely than individuals who acquired precise SARS-CoV-2 antibodies without going through the disease.

To understand the range of variations in $\mathrm{X}$ (\% of population with pre-existing antibodies) and $\mathrm{F}$ (Amplification Factor for any virus-tested positive case), we repeat the calculations with a different set of data. We use the figures prior to adjustment for testing volumes, which also helps us understand the impact of Test Volume adjustment. Fitting the data:

\section{X F = $228300-X$... from Survey 1 , where figures are per million population, and $F$ is unit-less}

and, $\quad 6550 \times \mathrm{F}=278400-\mathrm{X} \ldots$ from Survey 2

implies, $\quad \underline{X=186706}(\underline{18.67 \%})$, and $F=14.0$

The results vary within a small range, with or without adjustments for testing volume. The pre-existing antibody coverage varies between $16 \%$ and $18.7 \%$, while the amplification factor varies between 15.9 and 14 .

\section{Conclusions}

This study reached the following conclusions:

1. Approximately $16 \%-19 \%$ of the population possesses preexisting antibodies, possibly cross-reactive antibodies of HCoV or other viruses, which provide immunity against the SARS-CoV-2 virus. These individuals test seropositive for SARS-CoV-2 IgG antibodies without undergoing the disease.

2. Every virus-tested positive case represents a larger number of virus-infected cases, uncounted because they are asymptomatic or otherwise untested. Every virus-tested positive case represents 14-16 cases. This finding formalises what has been observed in all serostudies.

These conclusions are subject to the limitations of this study described below and in the context of Delhi State only. Since the climatic, ecological, genetic and economic conditions of a community may impact the elements of this research, further work will be needed to check the applicability of these results to other geographical areas.

Based on the foregoing analysis, we forecast the outcome of the serosurvey scheduled to have taken place at Delhi between $1^{\text {st }}$ and $5^{\text {th }}$ September, for which the latest infections were $20^{\text {th }}$ August, and the results are expected around September $22^{\text {nd }}$, one week later than the date of this report. We expect seropravelence to be approximately $31 \%$ - 34\% for this survey. Anything vastly different from this would require re-examination of this study or thorough scrutiny of the serosurvey techniques.

Pre-existing seroprevalence and an amplification factor of invisible cases have implications for disease progression. For subsequent analysis, we will simplify to the following: $17 \%$ of the population has preexisting antibodies, and every virus-tested positive stands for 15 virus-infected cases.

\section{Limitations of this study.}

1. No peer-reviewed paper has yet been released by the agencies that conducted the serostudies at Delhi. Questions on sampling, methodology, time of testing and results interpretation remain open, and it is not possible to ascertain compliance with Guidelines for Covid 19 Antibody Testing issued by CDC, USA ${ }^{(11)}$.

2. The sensitivity (true-positive) and specificity (true-negative) scores of Covid 19 antibody testing kits remain under some debate. 
3. The attempt to equate testing volumes on the basis of spot positivity, though taken from established research, is still a sensitive area of this study. Sensitivity analysis done, however, shows that the variations are not large even if this adjustment is not done.

4. Various time-dependent parameters are actually probability distributions that have been simplified to their median values. The antibody generation time is one such out of many others.

5. Emerging research has the potential to change much of the current wisdom. Antibodies declining over time, Covid 19 recovered cases who do not develop antibodies, the role of Memory T cells and B cells (inherent versus adaptive versus acquired immunity), are examples of such research. Such possibilities are not considered in this study.

6. Covid 19 data is low quality worldwide, with reporting delays, bad data discipline, and more.

The study conclusions are significant despite limitations, and adequate care was exercised to make the conclusions quantitatively robust.

\section{Implications: How Does Preexisting Antibodies in 17\% of Population Impact Disease Progression?}

The short answer to this question is that it helps, but we don't know how much! Clearly, $17 \%$ are already immune and nonsusceptible. Those who contract the disease and recover acquire antibodies and become non-susceptible. These two categories we have so far called seroprevalent. Additionally, immunity is another category without antibodies - those with various forms of adaptive immunity, such as memory T-cells, non-specific advantages of BCG vaccination, etc. We have no idea of the proportion of such cases.

We know that the transmission efficiency (Reproduction Number) and the availability of a ready susceptible population are the two reasons that a pandemic grows. Similarly, two forces work together in unison to slow down a pandemic:

1. Virus Transmission Slows Down as number of Non-Susceptible (Infected or Immune) People Increase. [We strictly avoid the term Herd Immunity because it is deceptive, of limited utility and needlessly sensationalised.]

It is intuitively obvious that a virus that has a finite lifetime in open air finds it difficult to locate a fresh host if more and more people are already non-susceptible - it dies during the search!. This idea is rigorously presented in the differential equations that govern the Suspected-Infected-Recovered (SIR) model of epidemiology. Virus transmission slows down progressively as numbers of non-susceptibles increase - it is tougher for a virus to maintain growth-rate at $50 \%$ non-susceptible compared to $30 \%$ and even tougher at $70 \%$.

\section{Breaking the Chain of Transmission}

Whether susceptible or immune, if individuals and communities work to block the virus from getting to them, in theory, viruses will find no hosts, and disease will end. Conceptually, if the non-susceptible population is one that cannot become infected, those who put up barriers to transmission make themselves unavailable for infection. Individual protocols to break the chain of transmission (distancing, masks, etc.) are well known. Less understood is the role of non-Covid and Covid "bubbles". Monitored community pockets - e.g., gated residential complexes, old-age homes, monasteries - act as self-contained barriers to the chain of transmission. Some population subgroups (e.g., those with serious illness, superseniors and children $<5$ yrs) form logical bubbles. Equally, it is possible to "bottle-up" localized areas of the Covid outbreak by physical distancing and barriers the so-called containment zone. These now become Covid bubbles, insulated from contaminating the community outside. All these categories together reduce the number available for the virus to infect. Since chain-of-transmission protocols are not perfectly maintained by all people at all times, particularly over long durations, the number available to infect keeps going up and down.

Working together in unison. Both these measures work in unison. The virus has to make its way and find hosts to infect among those available for infection. If a large enough population effectively barriers themselves from the chain of transmission, say $20 \%$, then the virus has only $80 \%$ left for consideration, out of whom $40 \%$ may be non-susceptible. Viruses die in the effort to 
find hosts. Note that if $40 \%$ of people are immune and $50 \%$ of the population is well sheltered, the situation is as difficult for the virus as if $80 \%$ of people are immune.

\section{Implications: Disease Progression in Delhi}

Fig 2 presents the Disease Progression graph in Delhi, 7-day Moving Average. We define that an outbreak has "reached a peak" in an area when daily fresh cases fall to $2 / 3^{\text {rd }}$ of its highest value, and no daily number thereafter goes above $2 / 3^{\text {rd }}$ of the peak value. The graph shows that Delhi's highest daily caseload was on $26^{\text {th }}$ June when (the 7 -day MA) was 3446 . This became the peak when the daily caseload fell to 2237 on $6^{\text {th }}$ July, i.e., below $2 / 3^{\text {rd }}$ of the maximum value. However, after a long lull, daily caseloads rose again and touched 2404 on $5^{\text {th }}$ September, going higher than $2 / 3^{\text {rd }}$ of max value, nullifying the peak found earlier. Delhi is an example in Covid 19 progression where a peak was achieved and then lost. Delhi has not yet peaked.

Table 3 provides serological and other data on select dates.

\begin{tabular}{|c|c|c|c|c|c|c|c|c|c|}
\hline \multirow{2}{*}{\multicolumn{2}{|c|}{$\begin{array}{l}\text { Delhi Pop = } \\
19.1 \mathrm{mn} \\
\text { As on Date }\end{array}$}} & \multicolumn{5}{|c|}{ Caseload, Tests and Positivity } & \multicolumn{3}{|c|}{ SEROPRAVELENCE } \\
\hline & & $\begin{array}{l}\text { Total } \\
\text { Infections } \\
\text { till date }\end{array}$ & $\begin{array}{l}\text { Adjusted } \\
\text { Tests till } \\
\text { Date }\end{array}$ & $\begin{array}{l}\text { Total } \\
\text { Infections } \\
\text { per mn }\end{array}$ & $\begin{array}{l}\text { Total } \\
\text { Tests } \\
\text { per } \\
\text { mn }\end{array}$ & $\begin{array}{l}\text { Cumulative } \\
\text { Covid } \\
\text { Positivity } \\
\text { Rate }\end{array}$ & $\begin{array}{l}\text { Spot } \\
\text { Positivity } \\
\text { on Day D }\end{array}$ & $\begin{array}{l}\text { Positivity- } \\
\text { adjusted } \\
\text { Tot Infect } \\
\text { per mn }\end{array}$ & $\begin{array}{l}\text { Expected } \\
\text { Seropravelence } \\
(+)\end{array}$ \\
\hline $\begin{array}{l}20- \\
\text { Jun }\end{array}$ & $\begin{array}{l}1^{\text {st }} \\
\text { Survey }\end{array}$ & 56746 & 308688 & 2971 & 16162 & $18.38 \%$ & $22.32 \%$ & 4297 & $23.46 \% \star$ \\
\hline $\begin{array}{l}\text { 26- } \\
\text { Jun }\end{array}$ & $\begin{array}{l}\text { Max } \\
\text { Daily }\end{array}$ & 77240 & 402763 & 4044 & 21087 & $19.18 \%$ & $18.39 \%$ & 5331 & $25 \%$ \\
\hline $\begin{array}{l}21- \\
\text { Jul }\end{array}$ & $\begin{array}{l}2^{\text {nd }} \\
\text { Survey }\end{array}$ & 125096 & 851311 & 6550 & 44571 & $14.70 \%$ & $6.90 \%$ & 7454 & $29.10 \% \star$ \\
\hline $\begin{array}{l}20- \\
\text { Aug }\end{array}$ & $\begin{array}{l}3^{\text {rd }} \\
\text { Survey }\end{array}$ & 157354 & 1375193 & 8238 & 72000 & $11.44 \%$ & $6.98 \%$ & 9388 & $31 \%-34 \%$ \\
\hline \multirow[t]{2}{*}{$\begin{array}{l}\text { 6- } \\
\text { Sep }\end{array}$} & $\begin{array}{l}\text { Latest } \\
\mathrm{dt}\end{array}$ & 191449 & 1780512 & 10024 & 93221 & $10.75 \%$ & $9.13 \%$ & 11855 & $35 \%-39 \%$ \\
\hline & \multicolumn{4}{|c|}{ (+) Visible 13 days after given date } & $A$ & * Announced & & & \\
\hline
\end{tabular}

Note: The total immune \% would include those with adaptive immunity, in addition to seroprevalent \%. Assume any figure for this complete unknown.

The following observations are presented in the figure and table above:

1. When Delhi reached its maximum value on 26 June, the seropravelence was only approximately $25 \%$. This $\%$ - only $25 \%$ non-susceptible, $75 \%$ susceptible - is not high enough to slow down virus transmission significantly. This downturn in disease progression was because of chain-of-transmission barriers and not because of reaching a huge number of nonsusceptible cases. This is also borne out by the ease with which the trajectory took off after $18^{\text {th }}$ The next paragraph explains what happened

2. We know that events on-ground take 10-15 days to show up as distinct changes on the disease progression $\operatorname{graph}^{(20,21)}$. In the 10-day period until $14^{\text {th }}$ June, Delhi recorded approximately 6000 tests per day. In the 10 -day period after $14^{\text {th }}$ June, Delhi averaged $>14000$ tests per day. In other words, $14^{\text {th }}$ June onwards was cracked down, coupled with state-wide quarantining and isolation protocols, active contact tracing, and containment zones. These intense chain-of-transmission methods appeared on the graph in the last week of June, with a downturn in cases after a maximum. 
3. Unlock 3.0, the reduction of containment zones and lockdown fatigue after 6 intense weeks began on approximately $1^{\text {st }}$ The consequences are visible from $18^{\text {th }}$ Aug, when the disease graph shot up wildly. Migration of patients from areas around Delhi would have added to the problem.

4. The seropravelence $\sim 38 \%$ corresponding to $6^{\text {th }}$ Sept (when undertaken on $20^{\text {th }}$ Sept), combined with other immune categories, is reaching levels where virus transmission rates will soon slow down automatically. By current trends, the graph should see a plateauing and downturn starting in about two weeks, and this will be a permanent downward trajectory because of epidemiological considerations.

It is obvious that the $17 \%$ population with pre-existing antibodies significantly reduces the duration of the total pandemic in Delhi, although the disease will continue for some months with a downward-sloping graph. However, without this number with pre-existing antibodies, the time to reach a decisive maximum (before plateauing or slowing) would have been extended by another 2 months.

\section{Declarations}

\section{STATEMENT OF FUNDING AND ABSENCE OF COMPETING INTERESTS}

The author affirms that this research was entirely self-funded, and there is no conflict of interest or competing interest with any other entity or individual.

\section{References}

1. Press Information Bureau, Government of India, Seropravelence Study conducted by National Centre for Disease Control, Ministry of Health \& Family Welfare, Press Release, July 21, 2020

2. Press Trust of India, 1\% People in Delhi Developed Antibodies to Covid-19 Finds Latest Sero-Survey, quoted in Firstpost.com, Aug 20, 2020

3. populationu.com, Delhi Population, UN World Population Estimates, As of Sept 10, 2020

4. Long, Quan-Xin et al, Antibody Response to SARS-CoV-2 in Patients with Covid 19, Nature Medicine, April $29,2020$.

5. Regaldo, Antonio, Blood Tests Show 14\% of People Now Immune to Covid 19 in One Town in Germany, MIT Technology Review, April 2020

6. Stringhini, Sylvia et al, Seroprevalence of anti-SARS-CoV-2 IgG Antibodies in Geneva, Switzerland: A Population-Based Study, The Lancet, June 2020

7. Havers, Fiona P et al, Seroprevalence of Antibodies to sARS-CoV-2 in 10 Sites in the United States, Mar 23 - May 12, JAMA Internal Medicine, July 2020

8. Suri, Shobha, A Primer on Serology Testing, Observer Research Foundation, July 2020.

9. He, Xi et al, Temporal Dynamics in Viral Shedding and Transmissibility of Covid 19, Nature Medicine, August 2020

10. Widders, A et al, SARS-CoV-2: The Viral Shedding vs Infectivity Dilemma, Elsevier: Infection, Disease and Health, May 2020

11. Centre for Disease Control, USA, Interim Guidelines for Covid 19 Antibody Testing, August 2020

12. Bonnet, DG et al, Adjusted Wald Confidence Interval for a Difference of Binomial Proportions Based on Paired Data, J Educational and Behavioural Statistics V37 No. 4, August 2012

13. Sapkal, $\mathrm{G}$ et al, Development of an Indigenous IgG ELISA for the Detection of anti-SARS-CoV-2 IgG, Indian Journal of Medical Research, June 2020

14. Indian Council of Medical Research, ICMR Develops and Validates ... COVID KAVACH ELISA, Press Release, May 14, 2020

15. wikipedia.org, Sensitivity and Specificity, Version as of Sept 7, 2020

16. covid19india.org, Delhi Coronavirus Tracker, Update as of Sept 8, 2020

17. Favero, Nathan, Adjusting Confirmed Covid 19 Case Counts for Testing Volume, medRxiv, Preprint June 2020

Page $10 / 12$ 
18. Van der Heide,V, SARS-CoV-2 Cross Reactivity in Healthy Donors, Nature Reviews Immunology, June 2020

19. Ma, Z et al, Cross-Reactivity towards SARS-CoV-2: The Potential Role of low-pathogenic Human Coronavirus, The Lancet Microbe, August 2020

20. Dey, Smarajit, Modeling Covid19 in India (Mar 3 - May 7, 2020): How Flat is Flat, And Other Hard Facts, MedrXiv, Preprint, May 2020

21. Dey, Smarajit, The Epicentric Nature of Covid19 Progression in India, in preparation, September 2020

22. https://www.ndtv.com/coronavirus/india-covid-19-tracker quoting Ministry of Health and Family Welfare, India (https://www.mohfw.gov.in/) for daily data on Covid19 statistics in India, updated 8am daily.

\section{Figures}

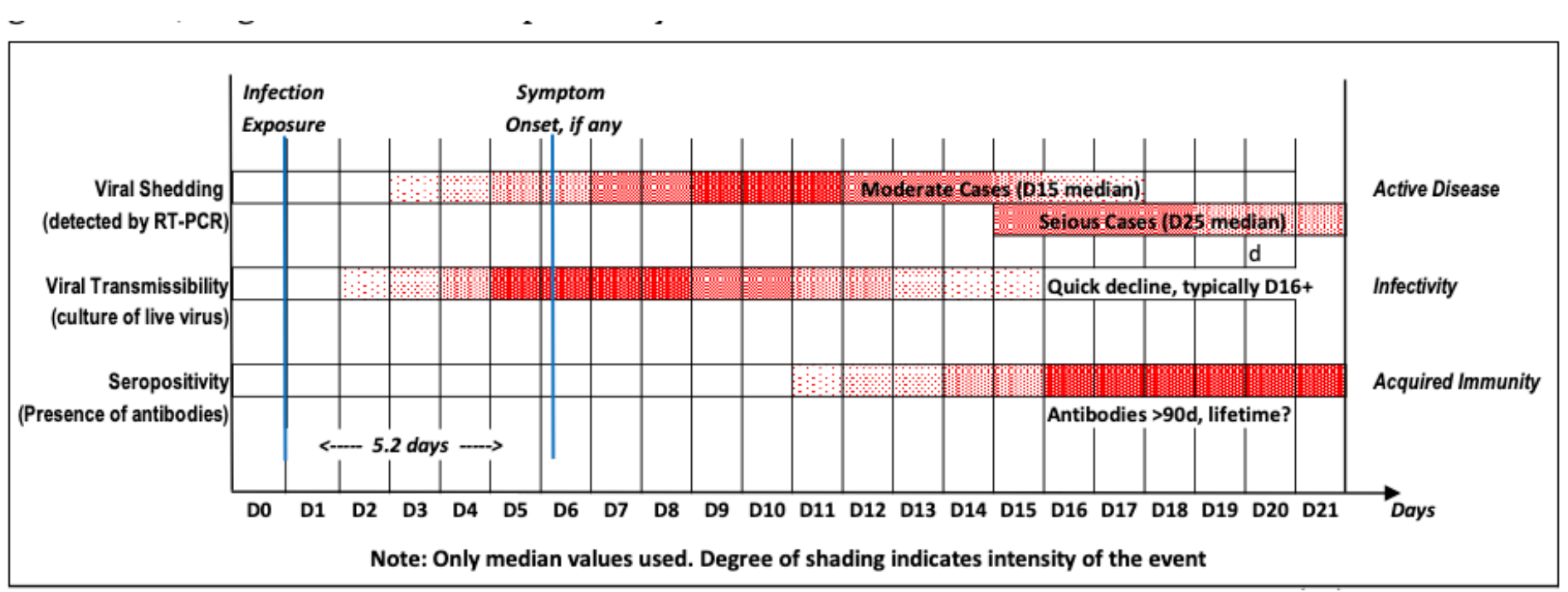

Figure 1

Simplified schematic showing time relationship between key COVID 19 events $(9,10)$ 


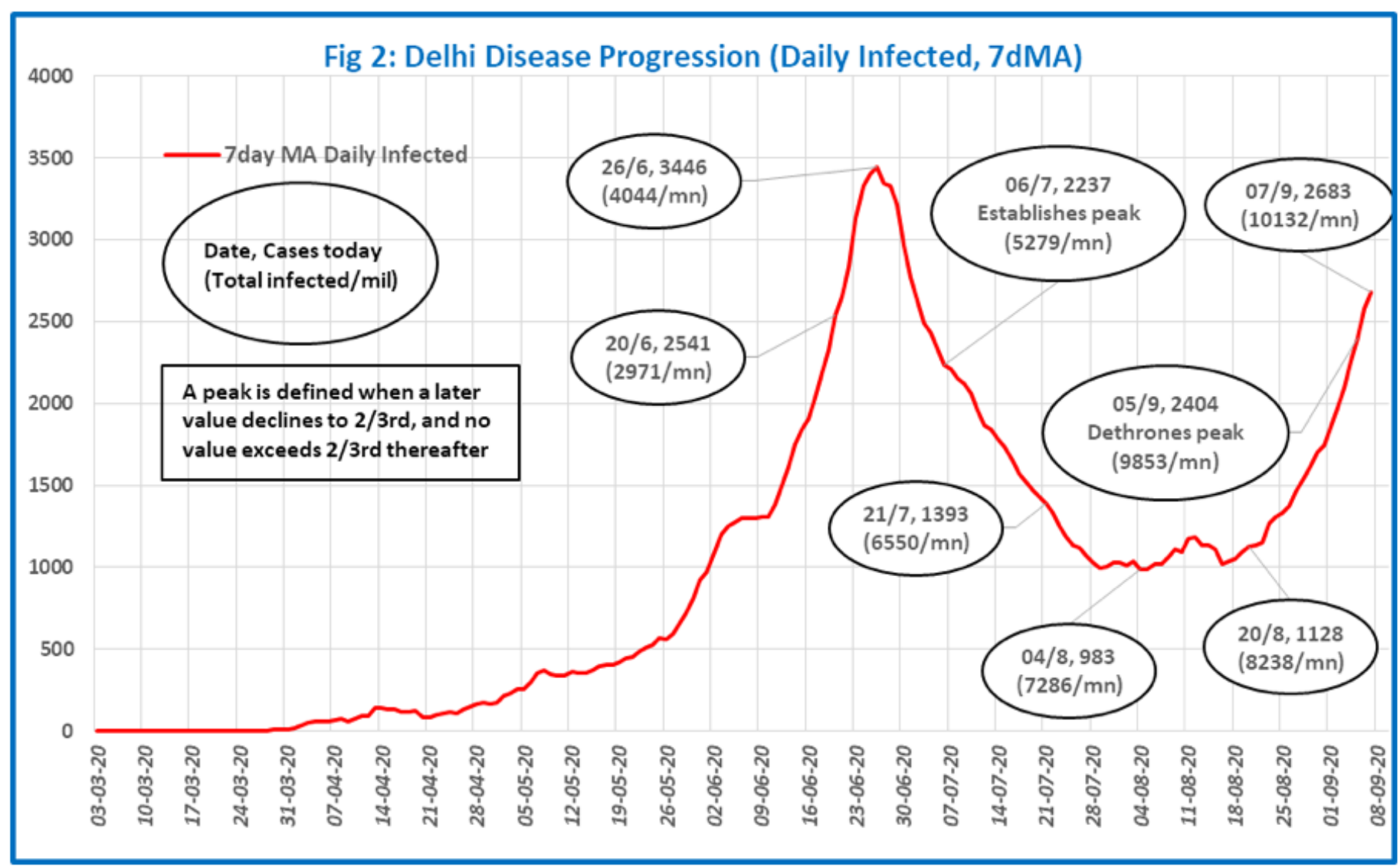

Figure 2

Delhi disease progression (daily infected, 7dMA) 